\title{
KINERJA BAGIAN UMUM SEKRETARIAT DAERAH KABUPATEN SUBANG
}

\author{
Ine Mariane ${ }^{1}$ \\ Fakultas Ilmu Sosial dan Ilmu Politik Universitas Pasundan \\ Ine.mariae@unpas.ac.id
}

\section{Tony Pathony ${ }^{2}$}

Fakultas Ilmu Administrasi Universitas Subang

topath12do@gmail.com

\begin{abstract}
Abstrak
Penelitian ini pada dasarnya merupakan penelitian kualitatif yang menggunakan metodi deskriptif kualitatif yang ditujukan untuk menggali secara deskriptif terkait kinerja pegawai di Bagian Umum Asisten Administrasi Umum Sekretaris Daerah Kabupaten Subang. Dalam penelitian ini ada tiga informan yang menjadi sumber data utama yang akan digali dan dianalisis untuk menjawab pertanyaan dalam penelitian ini. Adapun alat untuk menggali dan menganalisis kinerja pegawai ini menggunakan teknik wawancara yang setiap butir pertanyaannya mengacu kepada konsep kinerja pegawai yang berkategorikan kuantitas, kualitas, waktu, kehadiran dan kerjasama. Serta ditunjang dengan data lain berdasarkan faktor-faktor individu dan lingkungan yang memberikan pengaruh langsung kepada kinerja pegawai, yakni kemampuan, kepemimpinan, tim, sitem dan kontekstual. Berdasarkan hasil penelitian yang telah diuraikan pada bab sebelumnya, maka dapat disimpulkan bahwa kinerja pegawai pada Bagian Umum Asisten Administrasi Umum Sekretaris Daerah Kabupaten Subang secara umum dapat dikatakan sudah baik, berdasarkan hasil wawancara mendalam dengan informan-informan terkait maka kondisi kinerja pegawai di bagian umum tersebut dalam kondisi baik.
\end{abstract}

Kata Kunci: Kinerja Pegawai, Organisasi Kerja, Bagian Umum Setda Kabupaten Subang

\section{Abstract}

This research is basically a qualitative research that uses descriptive qualitative methods aimed at exploring descriptively related to employee performance in the General Section of the Assistant General Administration of the Regional Secretary of Subang Regency. In this study there are three informants who are the main data sources that will be extracted and analyzed to answer the questions in this study. The tool for exploring and analyzing employee performance uses interview techniques which each question refers to the concept of employee performance categorized as quantity, quality, time, attendance and cooperation. And supported by other data based on individual factors and the environment that provides a direct influence on employee performance, namely ability, leadership, team, system and contextual. Based on 


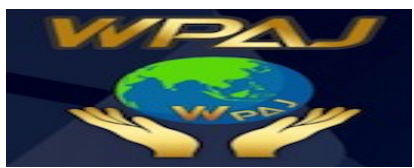

the results of the research described in the previous chapter, it can be concluded that the performance of employees in the General Administration Assistant Section of the General Secretary of Subang Regency in general can be said to be good, based on the results of in-depth interviews with related informants, the performance conditions of employees in the general section are good condition.

Keywords: Employee Performance, Work Organization, General Section of Subang

\section{Pendahuluan}

Setiap organisasi atau instansi dalam melaksanakan program selalu diarahkan untuk mencapai tujuannya. Salah satu faktor yang menjadi kriteria untuk mencapai kelancaran tujuan suatu organisasi atau instansi adalah mengidentifikasi dan mengukur kinerja pegawainya. Organisasi merupakan suatu kesatuan kompleks yang berusaha mengalokasikan sumber daya manusia secara penuh demi tercapainya suatu tujuan. Apabila suatu organisasi mampu mencapai tujuan yang telah ditetapkan, maka dapat dikatakan bahwa organisasi tersebut efektif. Seiring dengan perkembangannya, semua organisasi dituntut untuk dapat bersaing memberikan pelayanan yang maksimal, tidak terkecuali organisasi pemerintah. Demikian halnya dengan aparat pemerintah sebagai abdi masyarakat dan abdi pemerintah,dituntut untuk dapat memberikan pelayanan yang terbaik kepada masyarakat karena hal tersebut sudah merupakan salah satu fungsi yang harus dijalankan oleh pemerintah yang mempunyai tugas menyelenggarakan seluruh proses pelaksanaan pembangunan dalam berbagai sektor kehidupan mulai dari tingkat pusat hingga tingkat daerah.

Dalam era globalisasi dan seiring dengan kemajuan zaman, sebagai suatu instansi pemerintah yang melayani masyarakat, instansi pemerintah juga dituntut mampu untuk menyesuaikan diri dengan lingkungan dan perkembangan yang terjadi serta terus melakukan perubahan-perubahan. Tercapainya tujuan organisasi sangat ditentukan dari kinerja dan keefektifan para pegawai dalam menjalankan tugas. Setiap organisasi pada umumnya mengharapkan para pegawainya mampu melaksanakan tugasnya dengan efektif, efisien, produktif dan profesional. Semua ini bertujuan agar organisasi memiliki sumber daya manusia yang berkualitas dan sekaligus memiliki daya saing yang tinggi, sehingga nantinya akan menghasilkan kualitas pelayanan masyarakat yang sesuai dengan harapan masyarakat.

Sumber daya manusia merupakan salah satu faktor utama dalam setiap organisasi ataupun perusahaan. Tanpa adanya sumber daya manusia yang handal tujuan yang ada hanya akan menjadi cita-cita atau angan-angan belaka, meskipun fasilitas atau sumber daya pendukung lainnya berlimpah. Hal ini merupakan tugas manusia sebagai pelaksana dalam setiap kegiatan managemen. Sumber daya manusia yang berkualitas akan menentukan keberhasilan dari organisasi atau perusahaan itu sendiri, mulai dari tahap perencanaan, pelaksanaan, sampai tahap evaluasi sekalipun membutuhkan peranan sumber daya manusia. Hal ini membuktikan bahwa manusia sebagai kunci pokok yang harus di perhatikan segala kebutuhannya.

Suatu Organisasi atau perusahaan harus berusaha menjamin agar faktor yang berkaitan dengan produktivitas atau motivasi kerja dapat dipenuhi secara maksimal, 


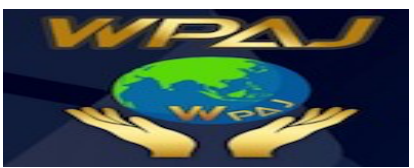

salah satu faktor diantaranya adalah kinerja pegawai. Kenyamanan kinerja pegawai dapat memicu pegawai untuk bekerja lebih baik dan optimal.Kinerja Pada Bagian Umum Sekretariat Daerah Kabupaten Subang juga di tentukan oleh lingkungan kerja yang harmonis antara semua pihak, yaitu kepala Bagian dan para pegawai Bagian Umum Sekretariat Daerah Kabupaten Subang. Banyak hal yang mempengaruhi kinerja pegawai Bagian Umum Sekretariat Daerah Kabupaten Subang. yang antara lain adalah lingkungan kerja yang kondusif, pengetahuan, penggunaan alat, sikap perbaikan dan disiplin, tanggung jawab, motivasi, kemampuan, keterampilan seta teknik-teknik manajerial.

Pada dasarnya setiap organisasi akan menghadapi perubahan lingkungan yang bersifat teknis fenomatik. Untuk mendukung motivasi kerja pegawai dapat dilakukan dengan menciptakan kinerja pegawai yang menyenangkan, kinerja pegawai merupakan suatu hasil kerja pegawai yang di berikan oleh atasannya dan bertanggung jawab atas apa yang telah diberikan.

Lingkungan kerja yang kondusif, pengetahuan, penggunaan alat sikap perbaikan dan disiplin, tanggung jawab, motivasi, kemampuan, keterampilan, serta teknik-teknik manajerial mempunyai pengaruh terhadap kinerja pegawai dalam usaha untuk menyelesaikan tugas-tugas yang dibebankan kepadanya dan akhirnya berpengaruh terhadap produktivitas kinerja pegawai, lingkungan yang baik akan meningkatkan hasil kerja yang baik, begitu pula sebaliknya apabila lingkungan kerja yang kurang tenang, akan mempertinggi tingkat kesalahan yang mereka lakukan. Besar pengaruhnya kinerja pegawai terhadap peningkatan produktivitasnya setiap lembaga tentu akan berbeda - beda, tetapi lembaga yang dapat berkembang dengan baik, pada umumnya adalah lembaga yang selalu melakukan inovasi yang tiada henti-hentinya. Lembaga yang yang inofatif adalah lembaga yang dapat menyesuaikan diri dengan lingkungan yang di hadapi untuk menunjang produktivitasnya agar kecil kemungkinan mengalami penurunan. Oleh karena itu faktor-faktor kerja harus menjadi perhatian dalam meningkatkan motivasi pegawai. Sementara motivasi kerja juga memberikan kontribusi yang besar bagi kinerja pegawai Bagian Umum Sekretariat Daerah Kabupaten Subang. Motivasi kerja merupakan dorongan, semangat dan inspirasi kerja yang ada dalam seseorang pegawai untuk bekerja lebih giat dan lebih baik. Menurut Robins dalam blog Ucihaitchi menyatakan bahwa mendefinisikan motivasi kerja sebagai proses yang berperang pada intensitas, arah dan lamanya berlangsung supaya ke arah pencapaian sasaran. Motifasi kinerja pegawai Bagian Umum Sekretariat Daerah Kabupaten Subang merupakan salah satu faktor yang menentukan kinerja pegawai Bagian Umum Bagian Umum Sekretariat Daerah Kabupaten Subang dalam memberikan layanan terhadap atasannya dan ke para pegawai yang lain yang ada di lembaga tersebut. Kutipan lisan dari pejabat yang berada di lingkup setda Kab. Subang yaitu tugas bawahan adalah membuat atasanya sukses dalam arti memberikan kinerja yang baik sehingga menghasilkan pekerjaan yang optimal demikian juga sebaliknya tugas atasan adalah membuat bawahannya sukses dalam arti memberikan kesejahteraan yaitu mempromosikan bawahannya naik jabatan.

Setelah melakukan observasi awal dan mewawancarai beberapa pagawai Bagian Umum di Sekretariat Daerah Kab. Subang yaitu beliau mengatakan bahwa kinerja pegawai Bagian Umum di Sekretariat Setda Subang tersebut sangat baik, dari 


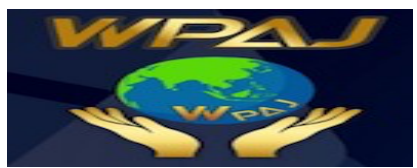

pernyataan itulah sehingga tertarik ingin mengkaji dan melihat seberapa besar kinerja Bagian Umum dalam mencapi tujuan kelembagaan/ Bagian tersebut.

\section{Kerangka Teori \\ Kinerja}

Kinerja sudah menjadi kata populer yang sangat menarik dalam pembicaraan manajement publik. Konsep kinerja pada dasarnya dapat dilihat dari dua segi yaitu kinerja pegawai ( perindividu ) dan kinerja organisasi. Kinerja adalah gambaran mengenai tingkat pencapaian pelaksanaan tugas dalam suatu organisasi dalam upaya mewujudkan sasaran, tujuan, visi dan misi organisasi tersebut ( Bastian, 2006:274 )

Konsep kinerja dapat didefinisikan sebagai sebuah pencapaian hasil ( Rue dan byars, 1981 dalam keban 2005 : 59 ). Hal ini berarti bahwa kinerja suatu organisasi itu dapat dilihat dari tingkatan sejauh mana organisasi dapat mencapai tujuan yang didasarkan pada tujuan yang sudah ditetapkan sebelumnya. Kinerja merupakan hasil dari kegiatan kerjasama diantara anggota atau komponen organisasi dalam rangka mewujudkan tujuan organisasi. Sederhananya kinerja merupakan produk dari kegiatan administrasi yaitu kegiatan kerjasama dalam sebuah organisasi atau kelompok untuk mencapai tujuan yang pengelolaannya biasa disebut dengan manajement.

Kinerja dikatakan sebuah hasil ( output)dari suatu proses tertentu yang dilakukan oleh seluruh komponen organisasi terhadap sumber-sumber tertentu yang digunakan ( input). Selanjutnya kinerja juga merupakan hasil dari serangkaian proses kegiatan yang dilakukan untuk mencapai tujuan tertentu sebuah organisasi. Dalam kerangka organisasi terdapat hubungan anatara kinerja perorangan (Individual Performance )dengan kinerja organisasi ( Organization Performance). Organisasi pemerintah maupun swasta besar maupun kecil dalam mencapai tujuan yang telah ditetapkan harus melalui kegiatan - kegiatan yang digerakan oleh orang atau sekelompok orang yang aktif berperan sebagai pelaku dengan kata lain tercapainya tujuan organisasi hanya dimungkinkan karena adanya upaya yang dilakukan oleh orang dalam organisasi tersebut.

Kinerja merupakan suatu fungsi dari motifasi dan kemampuan untuk menyelesaikan tugas atau pekerjaan. Seseorang sepatutnya memiliki derajat kesediaan dan tingkat kemampuan tertentu. Kesediaan dan keterampilan seseorang tidaklah cukup efektif untuk mengerjakan sesuatu tanpa pemahaman yang jelas tentang apa yang akan dikerjakan dan bagaimana mengerjakanya.

Pernyataan Smith yang dikutip oleh Sedarmayanti ( 2001 : 50 ) Mengungkapkan bahwa: output drive from processes, human or otherwise, jadi dikatakannya bahwa kinerja merupakan hasil atau keluaran dari suatu proses. kinerja merupakan hasil dari suatu proses.Sedangkan menurut Efendy ( 2002 : 194 ) mengatakan bahwa: Kinerja adalah unjuk kerja yang merupakan hasil kerja yang dihasilkan oleh pegawai atau prilaku nyata yang ditampilkan sesuai dengan perannya dalam organisasi. Berbeda dengan pendapat diatas, menurut (Mahsun, 2006 :25) mengemukakan definisi kinerja yaitu: Gambaran mengenai tingkat pencapaian pelaksanaan suatu kegiatan/program/kebijakan dalam mewujudkan sasaran, tujuan, misi, dan visi organisasi yang tertuang dalam strategic planning suatu organisasi. 


\section{Manajemen Kinerja}

Manajemen kinerja adalah suatu proses strategi dan terpadu yang menunjang keberhasilan organisasi melalui pengembangan performance SDM. Dalam manajement kinerja kemampuan SDM sebagai kontributor individu dan bagian dari kelompok dikembangkan melalui proses bersama antara manajer dan individu yang lebih berdasarkan kesepakatan daripada intruksi. Kesepakatan ini meliputi persyaratan pengetaahuan,keterampilan dan kemampuan serta pengembangan kinerja dan perencanaan pengembangan pribadi.

Ditinjau dari bunyi kalimatnya, manajemen kinerja ini berkaitan dengan usaha, kegiatan atau program yang diprakarsai dan dilaksanakan oleh pimpinan organisasi ( Perusahaan ) untuk merencanakan, mengarahkan dan mengendalikan prestasi karyawan. Karena program ini mencantumkan kata manajement, seluruh yang dilakukan dalam sebuah proses manajemen harus terjadi, yakni dimulai dari menetapkan tujuan yang ingin dicapai, pembuatan rencana, pengorganisasian, penggerakan atau pengarahan dan akhirnya evaluasi atau hasil. Secara teknis program ini harus dimulai dengan menetapkan tujuan dan sasaran yaitu "Kinerja dalam bentuk apa dan yang bagaimana yang ingin dicapai ". Karena yang menjadi obyek adalah kinerja manusia, maka bentuk yang paling umum tentunya adalah kinerja dalam bentuk " Produktivitas " sumber daya manusia ( Ruky, 2001:7)

Tujuan yang biasanya dapat dicapai oleh sebuah organisasi atau perusahaan dengan menerapkan sistem manajemen kinerja seperti pendapat Ruky (2001 :39) dapat dilihat dari uraian berikut.

1. Meningkatkan prestasi kerja karyawan baik secara individu maupun sebagai kelompok sampai setinggi-tingginya dengan memberikan kesempatan pada mereka untuk memenuhi kebutuhan aktualisasi dirinya dalam kerangka pencapaian tujuan perusahaan. Karyawan bersama atasan masing-masing dapat menerapkan sasaran kerja dan standar prestasi yang harus dicapai dan meneliti serta menilai hasil-hasil yang sebenarnya dicapai pada akhir kurun waktu yang ditetapkan.

2. Peningkatan yang terjadi pada prestasi karyawan secara perorangan pada gilirannya akan mendorong kinerja sumber daya manusia secara keseluruhan, yang direfleksikan dalam kenaikan produktifitas. Dengan kata lain peningkatan produktifitas sumber daya manusia secara keseluruhan diusahakan dicapai melalui peningkatan prestasi kerja karyawan secara perorangan (individu )

3. Merangsang minat dalam pengembangan pribadi dalam tujuan meningkatkan hasil karya dan prestasi pribadi serta potensi laten karyawan dengan cara memberikan umpan balik pada mereka tentang prestasi mereka.

4. Membantu perusahaan untuk dapat menyususn program pengembangan dan pelatihan karyawan yang lebih tepat guna. Usaha ini akan membantu perusahaan untuk mempunyai pasokan tenaga yang cakap dan terampil yang cukup untuk pengembangan perusahaan di masa depan.

5. Menyediakan alat/sarana untuk membandingkan prestasi kerja pegawai dengan tingkat gajinya atau imbalanya sebagai dari kebijakan dan sistem imbalan yang baik. 


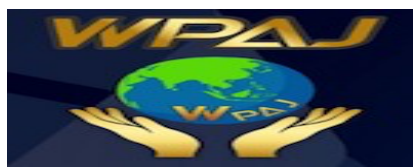

6. Memberikan kesempatan kepada pegawai untuk mengeluarkan perasaanya tentang pekerjaan atau hal-hal yang ada kaitanya. Dengan demikian jalur komunikasi dan dialog akan terbuka dan dengan demikian diharapkan bahwa proses penelitian prestasi kerja akan mengeratkan hubungan antara atasan dan bawahan.

Pentingnya penilaian untuk kerja menghendaki penilaian kinerja tersebut haras benar-benar obyektif, yaitu mengukur untuk kerja pegawai yang sesungguhnya (Effendi, 2002 : 199). Artinya pelaksanaan penilaian harus mencerminkan pelaksanaan untuk kerja yang sesungguhnya atau mengevaluasi perilaku yang mencerminkan keberhasilan pelaksanaan pekerjaan.

Mempunyai standar berarti mempunyai dimensi-dimensi yang menunjukkan perilaku kerja yang sedang dinilai, yang umumnya diterjemahkan dari sasaran kerja, misalnya hasil kinerja berupa barang yang dihasilkan, kualitas atau kuantitas, kehadiran ditempat kerja, kepatuhan terhadap peraturan dan faktor prestasi.

Namun, ada beberapa indikator yang biasanya digunakan untuk mengukur kinerja, seperti yang dikutip Dwiyanto $(2002: 48)$ yaitu sebagai berikut :

1. Responsivitas;

Responsivitas adalah kemampuan organsiasi untuk mengenali kebutuhan masyarakat. menyusun agenda dan prioritas pelayanan. dan mengembangkan program-program pelayanan, dan mengembangkan program-program pelayanan publik sesuai dengan kebutuhan dan aspirasi masyarakat secara singkat responsivitas ini menunjuk pada keselarasan antara program dan kegiatan pelayanan dengan kebutuhan dan aspirasi masyarakat. Responsivitas dimasukkan sebagai salah satu inaikaior kinerja karena responsivitas secara langsung menggambarkan kemampuan organisasi publik dalam menjalankan misi dan tujuannya, terutama untuk memenuhi kebutuhan masyarakat.

2. Responsibilitas;

Responsibilitas menjelaskan apakah pelaksanaan kegiatan organisasi publik itu dilakukan sesuai dengan prinsip-prinsip administrasi yang benar atau sesuai dengan kebijakan organisasi, baik yang eksplisit maupun implisit (Linvine, 1990). Oleh sebab itu itu, responsibilitas bisa saja pada suatu ketika berbenturan dengan reponsivitas.

3. Akuntabilitas;

Akuntabilitas publik menunjuk pada seberapa besar kebijakan dan kegiatan organisasi publik tunduk pada para pejabat politik yang dipilih oleh rakyat. Dalam konteks ini, konsep akuntabilitas publik dapat digunakan untilk melihat seberapa besar kebijakan dan kegiatan organisasi publik tersebut konsisten dengan kehendak masyarakat banyak.

4. Produktivitas;

Konsep produktivitas tidak hanya mengukur tingkat efisiensi, tetapi juga efektivitas pelayanan. Produktivitas pada umumnya dipahami secara umum sebagai rasio antara input dengan output.

5. Kualitas Layanan; 


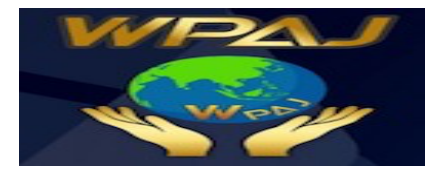

Isu mengenai kualitas layanan cenderung menjadi penting dalam menjelaskan kinerja organisasi publik. Hal ini disebabkan adanya pandangan negatif yang terbentuk mengenai organisasi publik muncul karena ketidakpuasan masyarakat terhadap kualitas layanan yang diterima. Dengan demikian kualitas layanan dapat dijadikan indikator kinerja organisasi publik.

Kinerja dalam lingkup organisasi adalah hasil kerja yang telah dicapai oleh suatu organisasi dalam melakukan suatu pekerjaan dapat dievaluasi tingkat kinerjanya. Berhasil tidaknya tujuan dan cita-cita dalam organisasi tergantung bagaimana proses kinerja itu dilaksanakan. Kinerja organisasi tidak lepas dari faktor-faktor yang dapat mempengaruhi. Berikut menurut pendapat Ruky (2001 : 7) faktor- faktor yang mempengaruhi kinerja organisasi adalah:

1. Teknologi yang meliputi peralatan kerja dan metode kerja yang digunakan untuk mengahasilkan produk atau jasa yang dihasilkan oleh organisasi. semakin berkualitas teknologi yang digunakan, maka akan semakin tinggi tingkat kinerja organisasi tersebut.

2. Kualitas input atau material yang digunakan oleh organisasi.

3. Kualitas lingkungan fisik yang meliputi keselamatan kerja, penataan ruangan, dan kebersihan.

4. Budaya organisasi sebagai pola tingkah laku dan pola kerja yang ada dalam organisasi yang bersangkutan.

5. Kepemimpinan sebagai upaya untuk mengendalikan anggota organisasi agar bekerja sesuai dengan standar dan tujuan organisasi.

6. Pengelolaan sumber daya manusia yang meliputi aspek kompensasi, imbalan. promosi dan lainnya.

Diatas menjelaskan mengenai faktor-faktor yang dapat mempengaruhi kinerja organisasi dalam pencapaian pelaksanaan tugas yang dilakukan oleh sebuah organisasi atau instansi pemerintahan. Meningkatkan kinerja dalam sebuah organisasi atau instansi pemerintah merupakan tujuan atau target yang ingin dicapai oleh organisasi dan instansi pemerintah dalam memaksimalkan suatu kegiatan yang telah di tetapkan sebelumnya.

Berhasil tidaknya tujuan dan cita-cita dalam organisasi pemerintahan tergantung bagaimana proses kinerja ltu dilaksanakan. kinerja tidak lepas dari faktor-faktor yang mempengaruhi. Berikut faktor-faktor yang mempengaruhi kinerja organisasi sebagaimana yang dikemukakan oleh Keith Davis dalam (Mangkunegara, 2006 : 13).

1. Faktor Kemampuan Ability Secara psikologis, kemampuan ability terdiri dari kemampuan potensi $I Q$ dan kemampuan reality knowledge + skill. Artinya pimpinan dan karyawan yang memiliki IQ superior, very jabatan dan terampil dalam menjalankan pekerjaan sehari-hari maka akan mudah menjalankan kinerja maksimal.

2. Faktor Motivasi Motivation motivasi diartikan sebagai suatu sikap attitude pimpinan dan karyawan terhadap terhadap situasi kerja situation dilingkungan organisasinya. Mereka yang bersikap positif fro terhadap situasi kerjanya akan menunjukan motivasi kerja tinggi dan sebaliknya jika mereka berpikir negatif kontra terhadap situasi kerjanya akan menunjukan pada motivasi kerja yang 


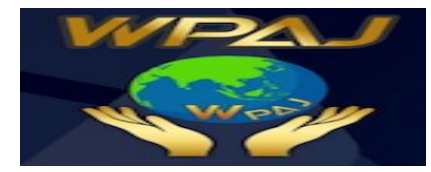

rendah. Situasi yang dimaksud meliputi hubungan kerja, fasilitas kerja, iklim kerja, kebijakan pimpinan, pola kepemimpinan kerja dan kondisi kerja.

Berdasarkan pengertian diatas bahwa suatu kinerja organisasi dapat dipengaruhi oleh beberapa faktor pendukung dan penghambat berjalannya suatu pencapaian kinerja yang maksimal faktor tersebut meliputi faktor yang berasal dari intern maunpun ekstern.

\section{Metode Penelitian}

Metode penelitian yang digunakan penulis di dalam penelitian ini adalah metode kualitatif. Dengan demikian penelitian ini menggambarkan fakta-fakta dan menjelaskan objek penelitian serta menggali informasi yang dibutuhkan sesuai dengan kenyataan sebagaimana adanya. Alasan pemilihan metode penelitan kualitatif penulis ingin memastikan kebenaran data yang ada dilapangan sehingga masalah yang sedang diteliti akan lebih jelas.

\section{Hasil dan Pembahasan}

\section{Kinerja Bagian Umum Sekretariat Daerah Kabupaten Subang}

Pembangunan Nasional bertujuan untuk mewujudkan masyarakat adil dan makmur berdasarkan pancasila dan UUD 1945. Berdasarkan Peraturan Bupati Subang Nomor: 49 Tahun 2019 Tentang Susunan Organisasi Perangkat Daerah Sekretariat Daerah dan Peraturan Bupati Subang Nomor 70 Tahun 2019 Tentang Tugas Pokok, Fungsi dan Tata kerja Sekretariat Daerah Kabupaten Subang.

Kinerja Bagian Umum Sekretariat Daerah Kabupaten Subang Melaksanakan penyiapan pelaksanaan kebijakan dan pemantauan dan evaluasi dibidang tata usaha pimpinan, staf ahli dan kepegawaian, perlengkapan dan rumah tangga;

Untuk menyelenggarakan tugas pokok sebagaimana dimaksud kepala bagian mempunyai tugas :

1. Penyusunan program kerja pada Bagian Umum;

2. Penyiapan bahan pelaksanaan kebijakan dibidang tata usaha pimpinan, staf ahli dan kepegawaian, perlengkapan dan rumah tangga;

3. Penyiapan bahan pelaksanaan pemantauan dan evaluasi dibidang tata usaha pimpinan, staf ahli dan kepegawaian, perlengkapan dan rumah tangga;

4. Penyusunan laporan hasil pelaksanaan kegiatan Bagian Umum;

5. Pelaksanaan fungsi lain yang diberikan oleh Asisten Administrasi Umum yang berkaitan dengan tugasnya.

Kemampuan kerja pegawai merupakan aspek penting dalam organisasi. Pegawai yang memiliki kemampuan kerja dalam melaksanakan tugas akan senantiasa bekerja percaya diri dan siap untuk menyelesaikan setiap permasalahan yang terjadi. Komunikasi dalam melaksanakan tugas dan tanggung jawabnya akan mempengaruhi kinerja yang diberikan dengan ditandai oleh tingkat produktivitas, kestabilan yang dimiliki dalam melaksanakan tugas, kedisiplinan yang kuat, loyalitas yang tinggi, tanggung jawab serta efektivitas dan efisiensi dalam melaksanakan tugas. Kedua aspek tersebut jika bersatu secara utuh dalam kondisi baik akan menjadikan pegawai berperilaku sesuai dengan tuntutan organisasi yang dikehendaki. Oleh 
karena itu apapun bentuk organisasinya aspek kemampuan kerja dan komunikasi perlu mendapatkan perhatian yang serius dari pimpinan organisasi tersebut.

Kinerja bisa juga dikatakan sebagai sebuah hasil (output) dari suatu proses tertentu yang dilakukan oleh seluruh komponen organisasi terhadap sumber-sumber tertentu yang digunakan (input). Selanjutnya, kinerja juga merupakan hasil dari serangkaian proses kegiatan yang dilakukan untuk mencapai tujuan tertentu organisasi. Bagi suatu organisasi, kinerja merupakan hasil dari kegiatan kerjasama diantara anggota atau komponen organisasi dalam rangka mewujudkan tujuan organisasi.

Wawancara yang dilakukan dalam penelitian ini yaitu wawancara kepada stakeholder di Asisten Administrasi Umum Daerah di wilayah kerja Setda Kabupaten Subang yaitu, Pertama, Kepala Bagian (Kabag) Umum Setda Kabupaten Subang sebagai informan kunci dan merupakan pemangku kebijakan terkait kepegawaian di Bagian Umum Setda Kabupaten Subang. Kedua, Kepala Sub. Bagian Umum Setda Kabupaten Subang sebagai user atau pelaksana langsung. Ketiga, Pegawai Bagian Umum Setda Kabupaten Subang sebagai user atau pelaksana langsung. Dari ketiga informan yang diwawancarai oleh peneliti, mendapatkan temuan-temuan yang mendasar terkait kinerja pegawai di Bagian Umum Setda Kabupaten Subang yang kemudian dipertimbangkan dengan prosedur atau regulasi tentang kinerja pegawai di Bagian tersebut.

Untuk mengetahui Kinerja Bagian Umum Sekretariat Daerah Kabupaten Subang sesuai dengan teori kinerja menurut pendapat;

Hersey et. all dalam Wibowo (2010 : 102) yang terdiri dari : 1) Tujuan, 2) Standar, 3) Umpan Balik, 4) Alat atau Sarana, 5) Kompetensi, 6) Motif, 7) Peluang. Adapun hasil penelitian dan pembahasan mengenai Kinerja Bagian Umum Sekretariat Daerah Kabupaten Subang yang di deskripsikan sebagai berikut:

\section{Tujuan}

Tujuan merupakan keadaan yang berbeda yang secara aktif dicari oleh seorang individu atau organisasi untuk dicapai. Pengertian tersebut mengandung makna bahwa tujuan bukanlah merupakan persyaratan, juga bukan merupakan sebuah keinginan.Tujuan merupakan sesuatu keadaan yang lebih baik yang ingin dicapai di masa yang akan datang. Dengan demikian, tujuan menunjukkan arah ke mana kinerja harus dilakukan. Atas dasar arah tersebut, dilakukan kinerja untuk mencapai tujuan. Untuk mencapai tujuan, diperlukan kinerja individu, kelompok, dan organisasi. Kinerja individu maupun organisasi berhasil apabila dapat mencapai tujuan yang diinginkan.

Hasil wawancara penulis dengan Kepala Bagian Umum Sekretariat Daerah Kabupaten Subang tentang Tujuan yang ingin dicapai adalah sebagai berikut: "Tujuan kerja di Bagian umum mewujudkan subang Jawara yaitu jaya istimewa sejahtera tentunya tidak jauh berbeda dengan bagian-bagian lainnya yang ada di lingkungan Setda Kabupaten Subang, walaupun bagian ini merupakan bagian yang baru saja dibentuk atas dasar perbup yang dikeluarkan oleh Bupati, namun pada dasarnya tidak jauh berbeda dengan tugas-tugas di bagian sebelumnya, cuman untuk selebihnya ya tinggal menyesuaikan saja dengan kondisi dan tugas yang ada. Sehingga soal Tujuan kerja yang pastinya tidak melebihi kemampuan dari pegawai yang ada, kecuali ada kondisi-kondisi tertentu yang bersifat mendesak" 
Berdasarkan hasil wawancara dengan Kepala Bagian Umum Sekretariat Daerah, bahwa Bagian Umum Sekretariat Daerah mempunyai tujuan mensejahterakan dan dapat mendorong pemanfaatan potensi sumberdaya manusia secara optimal dalam rangka meningkatkan Kinerja para pegawai sehingga terciptanya lingkungan kerja yang kondusif bagi peningkatan kualitas kerja yang lebih baik.

Berikut adalah hasil wawancara dengan Kepala Sub. Bagian Umum Sekretariat Daerah Kabupaten Subang tentang Tujuan yang ingin dicapai adalah sebagai berikut: "Sejauh ini, tujuan kerja menyiapkan pelaksanaan kebijakan dan pemantauan dan evaluasi dibidang kami , intinya tugas-tugas pekerjaan masih sesuai dengan kapasitas kami dan masih dapat dioptimalkan dengan baik dalam pengerjaannya"

Berikut adalah hasil wawancara dengan Pegawai. Bagian Umum Sekretariat Daerah Kabupaten Subang tentang Tujuan yang ingin dicapai adalah sebagai berikut"kalo, Tujuan kerja kami yaitu menyelesaikan dan dan mengerjakan tugas-tugas yang diperintahkan oleh pemimpin kami"

Optimal berarti seorang pemimpin unit kerja Sub. bagian umum dapat meminimumkan biaya atau penghematan penggunaan sumber daya untuk mencapai keluaran atau sasaran organisasi yang telah di tetapkan dapat di sebut manajer yang efisien. Suatu kegiatan dapat disebut efisien apabila dengan suatu usaha tertentu memberikan hasil yang sebabyak-banyaknya, mengenai mutunya ataupun jumlah satuan hasil itu. Konsepsi tentang efisien sebagai perbandingan terbaik antara suatu usaha dengan hasilnya itu dapat diterapkan dalam berbagai bidang, dari kehidupan pribadi yang bersifat perorangan sampai lapangan pekerjaan yang luas. Apabila diterapkan dalam bidangg kerja apapun, maka terdapatlah efisien kerja.

Berdasarkan hasil observasi dan hasil wawancara bahwa tujuan yang ingin dicapai oleh Bagian Umum Sekretariat Daerah Kabupaten Subang adalah memberikan pelayanan yang terbaik bagi Para Pegawai yang berada di Sekretariat Daerah Kabupaten Subang dan penyiapan pelaksanaan kebijakan dan pemantauan dan evaluasi dibidang tata usaha pimpinan, staf ahli dan kepegawaian, perlengkapan dan rumah tangga sehingga Organisasi pemerintahan berjalan optimal.

Berbagai kegiatan untuk mencapai tujuan organisasi dapat dikelompokkan dalam kegiatan-kegiatan yang secara langsung berkenaan dengan tujuan tugas pokok dan kegiatan-kegiatan penunjang kegiatan utama tersebut. Salah satu kegiatan penunjang dalam kegiatan organisasi adalah kegiatan perkantoran. Kegiatan perkantoran termasuk kegiatan penunjang yang sangat penting, dan bahkan sebagai urat nadi kehidupan organisasi. Hal ini karena kegiatannya menyangkut penanganan data dan informasi. Salah satu tugas seorang sekretaris (Staf Bagian Umum) ialah memberikan layanan terhadap pimpinan tingkat atasannya yang memerlukan bantuan penyediaan data dan informasi dalam melaksanakan fungsi dan perannya sebagai pemimpin (office manager) (Daryanto, 2010: 95).

\section{Standar}

Standar mempunyai arti penting karena memberitahukan kapan suatu tujuan dapat diselesaikan. Standar merupakan suatu ukuran apakah tujuan yang diinginkan dapat dicapai. tanpa standar, tidak dapat diketahui kapan suatu tujuan capai. Standar menjawab pertanyaan tentang kapan kita tahu bahwa kita sukses atau gagal. Kinerja 
seseorang dikatakan berhasil apabila mampu mencapai standar yang ditentukan atau disepakati bersama antara atasan dan bawahan.

Berikut hasil wawancara penulis dengan Kepala Bagian Umum Sekretariat Daerah mengenai standar kinerja yang telah ditetapkan oleh Bagian Umum Sekretariat Daerah Kabupaten Subang yaitu : "Standar Pekerjaan yang di laksanakan di Bagian Umum berjalan dengan efektif sesuai dengan tupoksinya masing-masing dan para pegawai bekerja berdasarkan kemampuannya sehingga pelaksanaan dalam pekerjaan efisien yang pasti paling utama itu dikembalikan kepada prosedur yang berlaku. Karena setiap instansi pemerintahan itu memiliki indicator untuk setiap pencapaian kerja yang dilakukan, sehingga setiap aktifitas kerja pegawai itu harus sesuai dengan prosedur-prosedur yang sudah ditetapkan"

Berikut adalah hasil wawancara dengan Kepala Sub. Bagian Umum Sekretariat Daerah Kabupaten Subang tentang Standar kinerja yang ingin dicapai adalah sebagai berikut: "Apa yang dikerjakan pastinya sesuai dengan prosedur yang ada dalam petunjuk teknis pekerjaan yang diberikan, jadi soal Standar Kinerja itu dikembalikan kepada pimpinan saja, pegawai sejauh ini menjalankan sesuai dengan apa yang diinstruksikan atau ditugaskan" Berikut adalah hasil wawancara dengan Pegawai. Bagian Umum Sekretariat Daerah Kabupaten Subang tentang Standar kinerja adalah sebagai berikut; "Pada dasarnya kebijakan yang dilaksankan oleh pimpinan sudah sesuai dengan tugas dan pekerjaan kami, tetapi ada kebijakan yang bukan bidang tuga kami harus melaksankan sehingga hal tugas tersebut mempengaruhi pelaksanaan tuga dan pekerjaan kami sendiri,apalagi pekerjaan kami juga mendesak untuk segera diselesaikan"

Dari penjelasan diatas, kita tahu bahwa bagian umum teleh memberikan hal yang maksimal selain itu mereka juga harus loyal dalam tugas yang mereka emban. Berdasarkan hasil observasi dan hasil wawancara bahwa standar Kinerja yang ingin dicapai oleh Bagian Umum Sekretariat Daerah Kabupaten Subang adalah sesuai dengan tupoksinya masing-masing dan para pegawai bekerja berdasarkan kemampuannya sehingga pelaksanaan dalam pekerjaan efisien.

\section{Umpan Balik}

Antara tujuan, standar, dan maupan balik bersifat saling terkait. Umpan balik melaporkan kemajuan, baik kualitas maupun kuantitas. dalam mencapai tujuan yang didefinisikan oleh standar. Umpan balik terutama penting ketika kita mempertimbangkan "real goals" atau tujuan sebenarnya. Tujuan yang dapat diterima oleh pekerja adalah tujuan yang bermakna dan berharga. Umpan balik merupakan masukan yang dipergunakan untuk mengukur kemajuan kinerja, standar kinerja, dan pencapaian tujuan, Dengan umpan balik dilakukan evaluasi terhadap kinerja dan sebagai hasilnya dapat dilakukan perbaikan kinerja.

Berikut hasil wawancara penulis dengan Kepala Bagian Umum Sekretariat Daerah mengenai Target kinerja yang telah ditetapkan oleh Bagian Umum Sekretariat Daerah Kabupaten Subang yaitu : "Penggunaan Target kinerja yang diberlakukan kepada pegawai sejauh ini dimanfaatkan dengan baik, jadi laporanlaporan kegiatan yang telah dilakukan dan juga kegiatannya berjalan sesuai target yang ditetapkan. Soal target kita memang memberikan perhatian khusus, karena penggunaan target itu berkaitan dengan penyerapan anggaran kalau di 


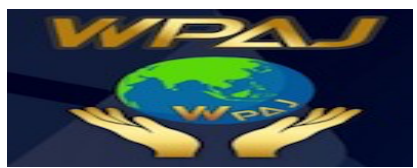

pemerintahan, jadi kita harus benar-benar memaksimalkan target yang telah ditetapkan"

Berikut adalah hasil wawancara dengan Kepala Sub. Bagian Umum Sekretariat Daerah Kabupaten Subang tentang target kinerja yang ingin dicapai adalah sebagai berikut: "Terkait Target kerja itu tidak bisa ditolelir, karena akan berimbas kepada aspek-aspek lainnya. Jadi tidak ada negoisasi lagi kalau urusan target itu harus tepat dan sesuai". Berikut adalah hasil wawancara dengan Pegawai Bagian Umum Sekretariat Daerah Kabupaten Subang tentang target kinerja yang ingin dicapai adalah sebagai berikut: "Target kerja sesuai dengan yang di perintahkan oleh pimpinan, karena sebagai pegawai kita harus menyelesaikan pekerjaan tersebut dengan sangat baik dan tepat waktu". Berdasarkan hasil observasi dan hasil wawancara bahwa target Kinerja yang ingin dicapai oleh Bagian Umum Sekretariat Daerah Kabupaten Subang adalah laporan-laporan kegiatan yang telah dilakukan dan juga kegiatannya berjalan sesuai target yang ditetapkan sesuai dengan rencana kerja dan Tupoksinya.

Dengan pertimbangan untuk melaksanakan ketentuan pasal 78 UndangUndang no 5 tahun 2014 tentang aparatur sipil negara, pada 26 april 2019, presiden joko widodo telah menandatangani peraturan pemerintah no 30 th 2019 tentang penilaian kinerja pegawai negeri sipil (PNS). (Tautan:PP no 30 th 2019). Menurut PP ini. Penilaian kinerja PNS bertujuan untuk menjamin objektivitas pembinaan PNS yang didasarkan pada sistem prestasi dan sistem karier.Penilaian dilakukan berdasarkan perencanaan kinerja pada tingkat individu dan tingkat unit atau organisasi, dengan memperhatikan target, capaian, hasil, dan manfaat yang dicapai, serta perilaku PNS.

\section{Alat atau Sarana}

Alat atau sarana merupakan sumber daya yang dapat dipergunakan untuk membantu menyelesaikan tujuan dengan sukses. Alat atau sarana merupakan faktor penunjang untuk pencapaian tujuan. Tanpa alat atau sarana, tugas pekerjaan spesifik tidak dapat dilakukan dan tujuan tidak dapat diselesaikan sebagaimana seharusnya, Tanpa alat tidak mungkin dapat melakukan pekerjaan.

Berikut hasil wawancara penulis dengan Kepala Bagian Umum Sekretariat Daerah mengenai Sarana dan Prasarana yang telah ditetapkan oleh Bagian Umum Sekretariat Daerah Kabupaten Subang yaitu : "Sampai sejauh ini sarana dan prasarana di Bagian Umum Sekretariat Daerah belum mencapai standar yang ada sarana perlengkapan kantor diantaranya komputer masih belum terpenuhi dan feximile belum ada pemeliharaannya sehingga informasi surat menyurat masih proses manual. Sedangkan prasarana seperti ruang kantor yang nyaman dengan bangunan standar, fasilitas AC ada namun pemeliharaanya kurang maksimal sehingga banyak yang rusak, pengaturan tata ruang kantor lumayan"

Berikut adalah hasil wawancara dengan kepala Sub Bagian Umum Sekretariat Daerah Kabupaten Subang tentang mengenai Sarana dan Prasarana yang telah ditetapkan adalah sebagai berikut: "Kalo......sarana dan prasarana sesuai dengan yang kami butuhkan sehingga pekerjaan / tugas yang di berikan oleh atasan dapat di selesaikan dengan baik dan efektif namun ada kendala dalam pemeliharaan sarana dana prasarana yaitu peralatan kantor komputer masih kurang dan yang ada masih 


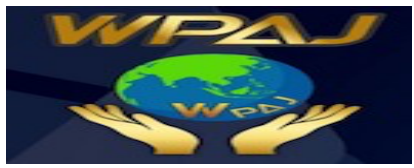

komputer keluaran jaman dulu jadi pekerjaan yang harus diselesaikan cepat menjadi lambat.Tidak adanya penyimpan listrik (genset) sehingga terjadi padam listrik kami tidak bisa melakukan aktivitas pekerjaan dan tidak ada pemeliharaan AC ruangan bila AC dalam ruangan rusak ". Berikut adalah hasil wawancara dengan Pegawai Bagian Umum Sekretariat Daerah Kabupaten Subang tentang mengenai Sarana dan Prasarana yang telah ditetapkan adalah sebagai berikut: "Menurut aku sih Sarana dan Prasarana masih kurang dan yang ada masih komputer keluaran jaman dulu jadi pekerjaan yang harus diselesaikan cepat menjadi lambat. "

Berdasarkan hasil observasi dan hasil wawancara bahwa Sarana dan prasarana yang ingin dicapai oleh Bagian Umum Sekretariat Daerah Kabupaten Subang belum memenuhi standar yang ada, sehingga dalam menyelengarakan kegiatannya untuk mencapai tujuan tidak akan tercapai.

Sarana lebih ditunjukan untuk benda bergerak seperti komputer, dan mesinmesin sedangkan prasarana lebih ditujukan untuk benda-benda yang tidak bergerak seperti gedung, ruang, tanah. sarana dan prasarana juga mempunyai arti dan maksud yang sma dengan istilah perbekalan kantor.

Tersedianya sarana dan prasarana kantor yang cukup dengan kualitas yang baik, sangat dibutuhkan pada setiap organisasi dimanapun dalam penyelenggarakan kegiatannya untuk mencapai tujuan. Demikian halnya kantor, tempat berlangsungnya kegiatan yang berkaitan dengan pekerjaan ketatausahaan/administrasi, juga sangat memerlukan sarana dan prasarana kantor. 1. Peralatan/ perlengkapan kantor dilihat dari bentuknya dapat dibedakan menjadi, 3 yaitu :

1. Peralatan / Perlengkapan berbentuk lembaran, yaitu kertas HVS, kertas folio bergaris, kertas karbon,kertas stenil.formulir, kertas berkop, plastik transparan, kertas karton, kertas bufallo, amplop dan map

2. Peralatan / Perlengkapan berbentuk non lembaran,yaitu pulpen, pensil, spidol, penghapus, penggaris, gunting, pemotong kertas/cutter, kalender, stempel,cap calender, bantalan stempel, jepitan kertas, tinta printer dll

2 Peralatan / Perlengkapan berbentuk buku, yaitu buku catatan, buku alamat relasi, buku telepon, kamus, peta kota-kota besar, buku tahunan, buku tamu, buku agenda surat, buku catatan keuangan, buku objek wisata (brosur/pamflet).

2. Peralatan/ perlengkapan kantor dilihat dari penggunaanya dapat dibedakan menjadi, 2 yaitu :

1. Barang pakai habis, yaitu barang/benda kantor yang penggunaannya hanya satu/beberapa kali pakai / tidak tahan lama. Contohnya Kertas, tintan,karbon,klip, pensil dan pulpen.

2. Barang tidak pakai habis, yaitu barang atau benda kantor yang penggunaannya tahan lama, Contohnya : stapler, Perforator, cutter dan gunting

Mesin mesin kantor adalah alat yang digunakan untuk menghimpun, mencatat, mengolah bahan- bahan keterangan dalam pekerjaan kantor yang bekerja secara mekanik, elektrik dan magnetik Contohnya komputer, laptop, mesin penghancur kertas, scanner, mesin absensi dll. Mesin komunikasi kantor yang digunakan untuk melakukan komunikasi baik di lingkungan organisasi sendiri maupun luar organisasi, contohnya telepon, feximile dan telepon wireless 


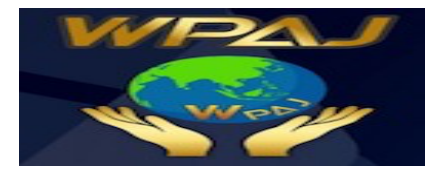

\section{Kompetensi}

Kompetensi merupakan persyaratan utama dalam kinerja. Kompetensi merupakan kemampuan yang dimiliki oleh seseorang untuk menjalankan pekerjaan yang diberikan kepadanya dengan baik, Orang harus melakukan lebih dari sekadar belajar tentang sesuatu, orang harus dapat melakukan pekerjaannya dengan baik. Kompetensi memungkinkan seseorang mewujudkan tugas yang berkaitan dengan pekerjaan yang diperlukan untuk mencapai tujuan.

Berikut hasil wawancara penulis dengan Kepala Bagian Umum Sekretariat Daerah mengenai Kompetisi yang telah ditetapkan oleh Bagian Umum Sekretariat Daerah Kabupaten Subang yaitu : "Kalau di tanya kompetensi kita sudah mencoaba sesuai dengan tugas pokok dan fungsinya sesuai jabatannya, dan wewenangnya masing-masing kemudian kita coba upayakan kalau dari staf juga mengerjakan halhal yang lebih spesifik sehingga jelas apa yang dikerjakan. Selain itu pekerjaan dilaksanakan seefektif mungkin. juga pembagian beban kerja juga sudah merata kepada seluruh staf". Berikut hasil wawancara penulis dengan Kepala Sub. Bagian Umum Sekretariat Daerah mengenai Kompetisi yang telah ditetapkan oleh Bagian Umum Sekretariat Daerah Kabupaten Subang yaitu : "Udah sesuai tupoksinya masing-masing, kan sudah di atur dalam peraturan yang ada, Sementara untuk beban kerja, semua bidang sudah dibebani pekerjaan yang merata dan selama ini juga tidak ada keluhan mengenai beban kerja yang lebih berat"

Berikut hasil wawancara penulis dengan Pegawai Bagian Umum Sekretariat Daerah mengenai Kompetisi yang telah ditetapkan oleh Bagian Umum Sekretariat Daerah Kabupaten Subang yaitu: "Untuk kompetensi kami dibebani pekerjaan yang merata dan selama ini juga tidak ada keluhan mengenai beban kerja yang lebih berat" Berdasarkan hasil observasi dan hasil wawancara bahwa kompetensi Kinerja yang ingin dicapai oleh Bagian Umum Sekretariat Daerah Kabupaten Subang sudah berdasarkan standar kerja dan menurut hasil dan pembagian beban kerja sudah merata pada seluruh pegawai yang ada.

\section{Motif}

Motif merupakan alasan atau pendorong bagi seseorang untuk melakukan sesuatu. Manajer memfasilitasi motivasi kepada karyawan dengan insentif berupa uang, memberikan pengakuan, menetapkan tujuan menantang, menetapkan standar terjangkau, meminta umpan balik, memberikan kebebasan melakukan pekerjaan. termasuk waktu melakukan pekerjaan, menyediakan sumber daya yang diperlukan dan menghapuskan tindakan yang mengakibatkan disintensif. Manusia merupakan salah satu faktor penentu tercapaiya tujuan organisasi, salah satu ukuran keberhasilan suatu instansi dilihat dari tingkat produktivitas manusianya. Produktivitas pekerjaan sebagian besar tergantung pada kemauan para pegawai nntuk menghasilkan sesuatu, untuk itu pimpinan harus berusaha agar para anggotanya mempunvai motivasi tinggi nntuk menjalankan tugasnya, dan disinilah pentingnya peranan motivasi.

Motivasi kerja dalam sebuah perusahaan atau instansi bertujuan untuk memacu karyawan agar lebih aktif dalam melaksanakan pekerjaan guna mencapai tujuan dan hasil yang optimal. Pelaksanaan motivasi kerja menitik beratkan pada faktor manusia di dalam melaksanakan aktivitasnya yaitu kerja. Keberadaan motivasi sangat penting peranannya, dalam usaha meningkatkan kualitas dan kuantitas kerja 
yang dihasilkan. Motivasi akan memberikan dorongan dan semangat bagi karyawan dan pimpinan. Adanya kepuasan kerja diharapkan akan menciptakan hubungan kerja yang harmonis antara kedua belah pihak yaitu karyawan dan pimpinan, sehingga tujuan instansi atau pemerintahan dapat tercapai dan berhasil secara optimal.

Berikut hasil wawancara penulis dengan Kepala Bagian Umum Sekretariat Daerah mengenai Motivasi yang telah ditetapkan oleh Bagian Umum Sekretariat Daerah Kabupaten Subang yaitu: "Motivasi dari kehadiran pegawai di Bagian Umum berjalan baik, hampir seluruh pegawai memiliki tingkat kehadiran yang tinggi, apalagi untuk saat ini kan diberlakukan bagi seluruh ASN bahwa kehadiran ini berkaitan juga dengan tunjangan kinerja setiap pegawai, jadi tidak bisa bolos-bolos seenaknya, jadi lebih bertanggung jawab untuk terus hadir memberikan pelayanan yang impresif, bahkan terkadang dihari libur juga masih ada yang menjalankan tugasnya"

Berikut hasil wawancara penulis dengan Kepala Sub. Bagian Umum Sekretariat Daerah mengenai Motivasi yang telah ditetapkan oleh Bagian Umum Sekretariat Daerah Kabupaten Subang yaitu : "Ini yang paling utama dan selalu kami jaga, kehadiran sangat penting bagi pegawai, karena kehadiran dapat mempengaruhi persoalan lainnya, bagaimana kerjaan dapat selesai dengan baik dan tepat waktu kalau kehadiran kita tidak optimal. Selain itu, kehadiran juga dapat mempengaruhi capaian kinerja secara keseluruhan baik peorangan ataupun dalam satu organisasi kerja".

Berdasarkan hasil observasi dan hasil wawancara bahwa Motivasi Kinerja yang ingin dicapai oleh Bagian Umum Sekretariat Daerah Kabupaten Subang optimal karana Motivasi kerja dalam Bagian Umum Sekretariat Daerah bertujuan untuk memacu karyawan agar lebih aktif dalam melaksanakan pekerjaan guna mencapai tujuan dan hasil yang optimal. Pelaksanaan motivasi kerja menitik beratkan pada faktor manusia di dalam melaksanakan aktivitasnya yaitu bertanggung jawab dan disiplin.

\section{Peluang}

Pekerja perlu mendapatkan kesempatan untuk menunjukkan prestasi kerjanya. Terdapat dua faktor yang menyumbangkan pada adanya kekurangan kesempatan untuk berprestasi, yaitu ketersediaan waktu dan kemampuan untuk memenuhi syarat. Tugas mendapatkan prioritas lebih tinggi, mendapat perhatian lebih banyak, dan mengambil waktu yang tersedia, jika pekerja dihindari karena tidak percaya terhadap kualitas atau kepuasan konsumen, mereka secara efektif akan di hambat dan kemampuan memenuhi syarat untuk berprestasi.

Munculnya otonomi daerah menyebabkan terjadinya pergeseran paradigma dari sistem pemerintahan yang bercorak sentralisasi mengarah kepada sistem pemerintahan yang desentralisasi, yaitu dengan memberikan keleluasaan kepada daerah dalam mewujudkan daerah otonom yang luas dan bertanggung jawab, untuk mengatur dan mengurus kepentingan masyarakat setempat sesuai kondisi dan potensi wilayahnya. Pemberian otonomi kepada daerah pada dasamya bertujuan meningkatkan daya guna dan hasil guna penyelenggaraan pemerintah daerah, 


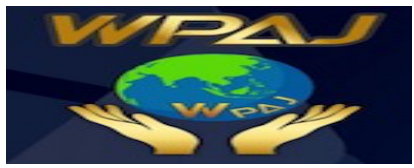

terutama dalam pelaksanakan pembartgunan dan pelayanan terhadap masyarakat serta untuk meningkatkan pembinaan kesatuan politik dan kesatuan bangsa.

Institusi pemerintah sebagai pelayan masyarakat perlu menemukan dan memahami cara yang profesional dalam rangka pemenuhan kebutuhan masyarakat, Dalam konteks pemerintahan, kebutuhan masyarakat menjadi tuntutan dan tanggung jawab pemerintah. Oleh karena itu, pemerintahan perlu diselenggarakan secara dinamis, tanggap, cepat dan tepat sasaran.

Berdasarkan Keputusan Menteri Pendayagunaan Aparatur Negara Nomor 63 tahun 2003 tentaug Pedoman Umum Penyelenggaraan Pelayanan Publik seperti prosedur pelayanan, persyaratan, kemampuan petugas pelayanan, kecepatan pelayanan, keadilan mendapatkan pelayanan, kepastian biaya pelayanan, dan kepastian jadwal pelayanan maka pemerintah memiliki konsekuensi untuk meningkatkan pelayanan dalam sektor pelayanan publik.

Salah-satu isu yang sangat menarik untuk dikaji adalah berkaitan dengan rendahnya efektivitas dalam pemberian pelayanan pada sebagian besar instansi pemerintah. Apabila kita mengamati fenomena yang terjadi pada masyarakat sampai saat ini masih banyak melakukan kerusuhan, unjuk rasa, demonstrasi secara berlebihan yang diakibatkan oleh rasa ketidakpercayaan masyarakat terhadap pemerintahan yang tidak sesuai dengan keinginan masyarakat. Selain itu, fenomena yang terjadi di kalangan masyarakat dan yang dikeluhkan baik itu dalam hal kepengurusan yang berwujud kepada pelayanan dari para oknum yang ter1ibat pada institusi tersebut.

Berikut hasil wawancara penulis dengan Kepala Bagian Umum Sekretariat Daerah mengenai Peluang yang telah ditetapkan oleh Bagian Umum Sekretariat Daerah Kabupaten Subang yaitu : "Pegawai yang berprestasi dan dan berdisiplin tinggi akan di berikan promosi oleh atasannya bila pendidikannya atau golongan pangkatnya sudah memadai adapun persoalan yang masih belum ada promosi jabatan itu di karenakan ada kebijakan yang lain dari atasan yang lebih tinggi ". Berikut hasil wawancara penulis dengan Kepala Sub. Bagian Umum Sekretariat Daerah mengenai Peluang yang telah ditetapkan oleh Bagian Umum Sekretariat Daerah Kabupaten Subang yaitu : "iya emang benar kalo peluang kanaikan pangkat atau promosi itu ada bila pegawai tersebut berprestasi dan disiplin kerja, kita sebagai pegawai harus bisa membuat atasan kita sukses sehingga dalam pekerjaan efisien "

Berikut hasil wawancara penulis dengan Pegawai Bagian Umum Sekretariat Daerah mengenai Peluang yang telah ditetapkan oleh Bagian Umum Sekretariat Daerah Kabupaten Subang yaitu : “Untuk kami sebagai pegawai peluang kanaikan pangkat atau promosi itu sangat berarti, karena dengan adanya itu membuat kami menjadi bisa berkarir ke jenjang yang berikutnya kalu istilahnya ke tingkat jabatan yang lebih tinggi, adapun kita sebagai pegawai harus bisa membuat atasan kita sukses sehingga dalam pekerjaan efisien adapun promosi kita sebagai pegawai hanya bisa bersabar ". Berdasarkan hasil observasi dan hasil wawancara bahwa Peluang Kinerja yang ingin dicapai oleh Bagian Umum Sekretariat Daerah Kabupaten Subang Masih belum optimal karena peluang kerja bertujuan memberikan kesempatan terhadap bawahanya untuk berprestasi lebih tinggi dalam artian naik jabatan atau promosi dan memberikan kesejahteraan kepada bawahannya sedangkan bawahannya juga harus bisa membuat atasannya sukses sehingga adanya kerjasama yang kuat antara 


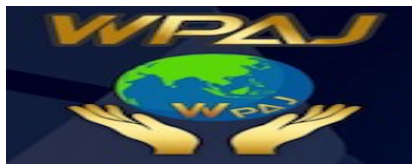

pemimpin dan pegawainya, Namun masih ada hambatan dalam proses kenaikan pangkat atau promosi dikarenakan masih adanya pegawai yang pangkatnya sudah memenuhi syarat promosi namun masih belum promosi jabatan semua itu merupakan kebijakan dari bupati dan pejabat petinggi Daerah.

\section{Kesimpulan}

Berdasarkan hasil penelitian yang penulis lakukan meugenai Kinerja Bagian Umum Sekretariat Daerah Kabupaten Subang, maka penulis merumuskan kesimpulan sebagai berikut:

1. Kinerja Bagian Umum Sekretariat Daerah Kabupaten Subang

a. Tujuan

Tujuan yang ingin dicapai oleh Bagian Umum Sekretariat Daerah Kabupaten Subang adalah memberikan pelayanan yang terbaik bagi Para Pegawai yang berada di Sekretariat Daerah Kabupaten Subang dan penyiapan pelaksanaan kebijakan dan pemantauan dan evaluasi dibidang tata usaha pimpinan, staf ahli dan kepegawaian, perlengkapan dan rumah tangga sehingga Organisasi pemerintahan berjalan optimal.

b. Standar

Standar kinerja yang ingin dicapai oleh Bagian Umum Sekretariat Daerah Kabupaten Subang adalah sesuai dengan tupoksinya masing-masing dan para pegawai bekerja berdasarkan kemampuannya sehingga pelaksanaan dalam pekerjaan efisien.

c. Umpan Balik

Umpan balik atau target kinerja yang ingin dicapai oleh Bagian Umum Sekretariat Daerah Kabupaten Subang adalah laporan-laporan kegiatan yang telah dilakukan dan juga kegiatannya berjalan sesuai target yang ditetapkan sesuai dengan rencana kerja dan Tupoksinya.

d. Alat atau Sarana

Sarana dan prasarana yang ingin dicapai oleh Bagian Umum Sekretariat Daerah Kabupaten Subang belum memenuhi standar yang ada, sehingga dalam menyelengarakan kegiatannya untuk mencapai tujuan tidak akan tercapai.

e. Kompetensi

kompetensi Kinerja yang ingin dicapai oleh Bagian Umum Sekretariat Daerah Kabupaten Subang sudah berdasarkan standar kerja dan menurut hasil dan pembagian beban kerja sudah merata pada seluruh pegawai yang ada.

f. Motif

Motivasi Kinerja yang ingin dicapai oleh Bagian Umum Sekretariat Daerah Kabupaten Subang optimal karena Motivasi kerja dalam Bagian Umum Sekretariat Daerah bertujuan untuk memacu karyawan agar lebih aktif dalam melaksanakan pekerjaan guna mencapai tujuan dan hasil yang optimal. Pelaksanaan motivasi kerja menitik beratkan pada faktor manusia di dalam melaksanakan aktivitasnya yaitu kerja bertanggung jawab dan disiplin.

g. Peluang

Peluang Kinerja yang ingin dicapai oleh Bagian Umum Sekretariat Daerah Kabupaten Subang Masih belum optimal karena peluang kerja bertujuan memberikan kesempatan terhadap bawahanya untuk berprestasi lebih tinggi 


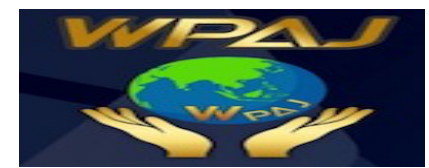

dalam artian naik jabatan / promosi dan memberikan kesejahteraan kepada bawahannya sedangkan bawahannya juga harus bisa membuat atasannya sukses sehingga adanya kerjasama yang kuat antara pemimpin dan pegawainya, Namun masih ada hambatan dalam proses kenaikan pangkat atau promosi dikarenakan masih adanya pegawai yang pangkatnya sudah memenuhi syarat promosi namun masih belum promosi jabatan semua itu merupakan kebijakan dari bupati dan pejabat petinggi Daerah.

\section{Referensi}

Indra, 2001, Akuntansi Sektor Publik di indonesia, Cetakan Pertama, yogyakarta: Prenada Media

Bagong, Suyanto,2005 Metode Penelitian Sosial : Berbagai Alternatif Pendekatan Jakarta : Prenada Media

Sedarmayanti, 2001, Sumberdaya Manusia dan produktivitas kerja, Bandung : Mandar Maju

Efendy Marihot Tua,2002, Manajemen Sumber Daya Manusia, Jakarta : Grasindo

Foster, Bob.2001, Manajemen Ritel, Bandung : Alfabet

Duncan, Tom, 2001, Principle Of Advertising and IMC. International Edition, Edisi Kedua McGrawhill.Newyork

Dwiyanto, Agus 2002 Mewujudkan Good Goverment melalui Pelayanan Publik, yogyakarta: UGM Press

Indrawijaya, 2006, Perilaku Organisasi, Jakarta: Sinar Baru

Keban,yeremias T. 2005, Enam Dimensi Strategis Administrasi Publik: Konsep, Teori dan Isu, Yogyakarta: Penerbit Gaya Media

Mangkunegara, A.A Anwar Prabu 2006, Manajemen Sumber Daya Manusia Perusahaan, Bandung : PT Remaja Rosdakarya

Moleong , lexy ,2000, Metode Penelitian Kualitatif, Bandung : PT Remaja Rosada Karya

Money D, James 2006, Konsep Pengembangan Organisasi Publik. Bandung : Sinar Baru Algesindo

Peraturan Bupati Subang Nomor: 49 Tahun 2019 Tentang Susunan Organisasi Perangkat Daerah Sekretariat Daerah

Peraturan Bupati Subang Nomor 70 Tahun 2019 Tentang Tugas Pokok, Fungsi dan Tata kerja Sekretariat Daerah Kabupaten Subang

Sugiyono, 2010, Metode Penelitian Administrasi, Bandung : Alfabet

Surjadi, 2009, Pengembangan Kinerja Pelayanan Publik. Bandung : Refika Aditama

Wibowo, 2010, Manajemen Kinerja, Jakarta Penerbit : Raja Grafindo Persada.

Wina Sanjaya, 2002, Metode Penelitian Pendidikan, Bandung, San Grafika. 